BIOMEDICAL AND BIOSOCIAL ANTHROPOLOGY
Official Journal of the International Academy
of Integrative Anthropology
journal homepage: http://bba-journal.com

\title{
Craniometric characteristic of the visceral skull in adulthood
}

\author{
Sazonova O. M., Vovk O. Yu., Vovk Yu. M., Hordiichuk D. O., Dubina S. O.
}

Kharkiv National Medical University, Kharkiv, Ukraine

\section{ARTICLE INFO}

Received: 2 July, 2018

Accepted: 16 August, 2018

UDC: $611.91-053.85: 572.71 / 76$

\section{CORRESPONDING AUTHOR}

e-mail: mega_darusi4ka@ukr.net Hordiichuk D.O.

\begin{abstract}
In relation with the development of clinical endovasive surgery, neurosurgery, maxillofacial surgery there is an urgent need for their improvement. Recent year's osteological and orthopedic areas of medicine have been rapidly developed; it requires an additional data on the age-related and individual anatomical variability. The purpose of the study - is to establish the range of anatomical variability of facial skull in adulthood taking in account the extreme forms, sizes and relations according to skull shapes. The research was conducted on a study of 100 bone samples of coherent and fragmented skulls from the collections of anatomy department of Kharkiv National Medical University. It was investigated 58 male skulls and 42 female skulls in 25-60 years old age. To establish an individual anatomical variability of the bone structures, was determined a number of main indices using the well-known craniodivider. All calculations performed by computer program "SPSS Statistics 17.0" using the digital standard package of the tables and initial data. It is proved that the highest range of the arithmetic average of zygomatic sizes (zy-zy) related with representatives of brachycephalic type of the skull, in adulthoods with mesocephalic type it decreases, the minimal range has been found in dolichocephalic type of the head and skull. The lower zygomatic diameter - the size between points go-go, also decreases in the arithmetic average from brachycephalic to dolichocephalic types that is associated with the gradual narrowing and lengthening of the visceral skull in adulthood. More stable results were found determining the forehead width (ft-ft). This parameter tends to decrease from brachycephalic to dolichocephalic. More advanced type of facial structure is defined in brachycephalic adulthoods, the narrowed forehead shape related with dolichocephalic type. For modern craniological estimation of the visceral skull, the size n-pr used to calculate special indices. According to our data, in brachycephalic males this parameter varies from 5.0 to $6.9 \mathrm{~cm}$; females - between $4.8-6.6 \mathrm{~cm}$. In representatives of mesocephalic type, the $n$-pr ranges in 10.0-11.6 cm. In people with dolichocephalic type, this altitude parameter increased in males from 5.7 to $7.9 \mathrm{~cm}$, females - from 5.5 to $7.6 \mathrm{~cm}$. It was also established that Ind1 has a wide range of variability, especially in brachycephalic males - 83.50 \pm 9.70 and in females - 87.00 \pm 7.80 , which includes a variety of visceral skull structure in people of different age. The range of this index in mesocephalic people is less - 86.00 \pm 3.20 (males) and $85.30 \pm 3.40$ (females). Accordingly, in dolichocephalic type complete visceral index is observed in range - $91.20 \pm 4.40$ (males) and $91.10 \pm 2.90$ (females). Thus, it is proved that the specific type of visceral skull - europrosopic is specific for the people of Kharkiv region. It is characterized by increased latitudinal sizes: zy-zy, po-po and go-go, with a slight decrease in altitude parameters of the visceral skull $n$-gn and $n$-pr. Depending on the range of variability of individual parameters of the visceral skull - it will be possible to suggest the most effective and rational ways of surgical interventions and accesses. Keywords: craniometry, individual anatomical variability, visceral skull, adulthood.
\end{abstract}

\section{Introduction}

Nowadays, specific directions of medicine become more popular, which associated with various operational or aesthetic interventions on the regions of the face, especially in adulthood. In relation with the development of clinical endovasive surgery, neurosurgery, maxillofacial surgery (that is often performs in adulthood) - appears the 
difficulties represented by differences in the visceral skull structures [1-10].

Features of the visceral skull formation, age-related transformations of its bony structures depend on gender and an individual human origins, has been found their place in the works of famous morphologists [12, 14, 15, $16-18,19,22,23]$. It is important to mention that in recent years osteological and orthopedic areas of medicine have been rapidly developed. It requires an additional data on the age-related and individual anatomical variability for the further development of academic V.N. Shevkunenko studies $[10,13,17,19-21,24-26]$.

The purpose of the study - to establish the range of anatomical variability of facial skull in adulthood taking in account the extreme forms, sizes and relations according to skull shapes.

\section{Materials and methods}

The research was conducted on a study of 100 bone samples of coherent and fragmented skulls from the collections of anatomy department of Kharkiv National Medical University. It was investigated 58 male skulls and 42 female skulls in 25-60 years old age. To establish an individual anatomical variability of the bone structures, was

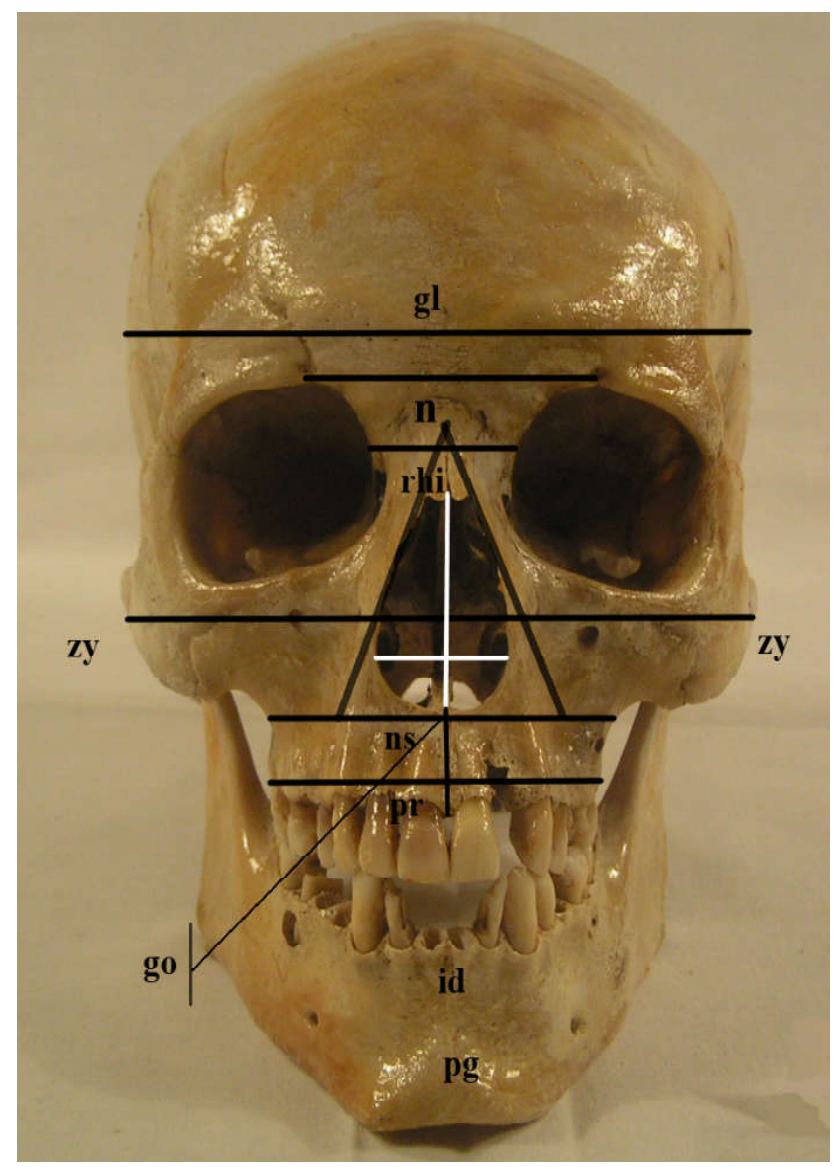

determined a number of main indices using the well-known craniodivider.

The main cranial index calculated using the formula: Ind = cranial transverse dimension (width) / skull's longitudinal size (length) $\times 100$, where the width is set between the parietal tubers corresponding to craniological point eurion (eu) and the length corresponding to the size from the bridge of the nose - point glabella $(\mathrm{gl})$ to the external occipital protuberance, related with a point opisthokranion (op). The ranges of primary cephalic index under 75 examined skulls related to dolichocephalic type; 75-79.9 mesocephalic type; 80 and over - brachycephalic.

One of the most important craniometric indicators - is facial index that is determined by the Garson's formula:

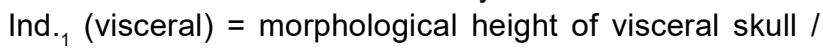
width of visceral skull (zygomatic size) x 100. According to this, the height of the visceral skull was measured between the junction of the fronto-nasal suture (on the root of the nose) at nasion point ( $\mathrm{n}$ ) and the most protruding part of the lower margin of the mandible, corresponding to the craniological point gnation (gn), and the width of the face corresponds to the zygomatic size (zy-zy).

If the above craniological points reflect everything, then we would get the Coleman's formula to determine the

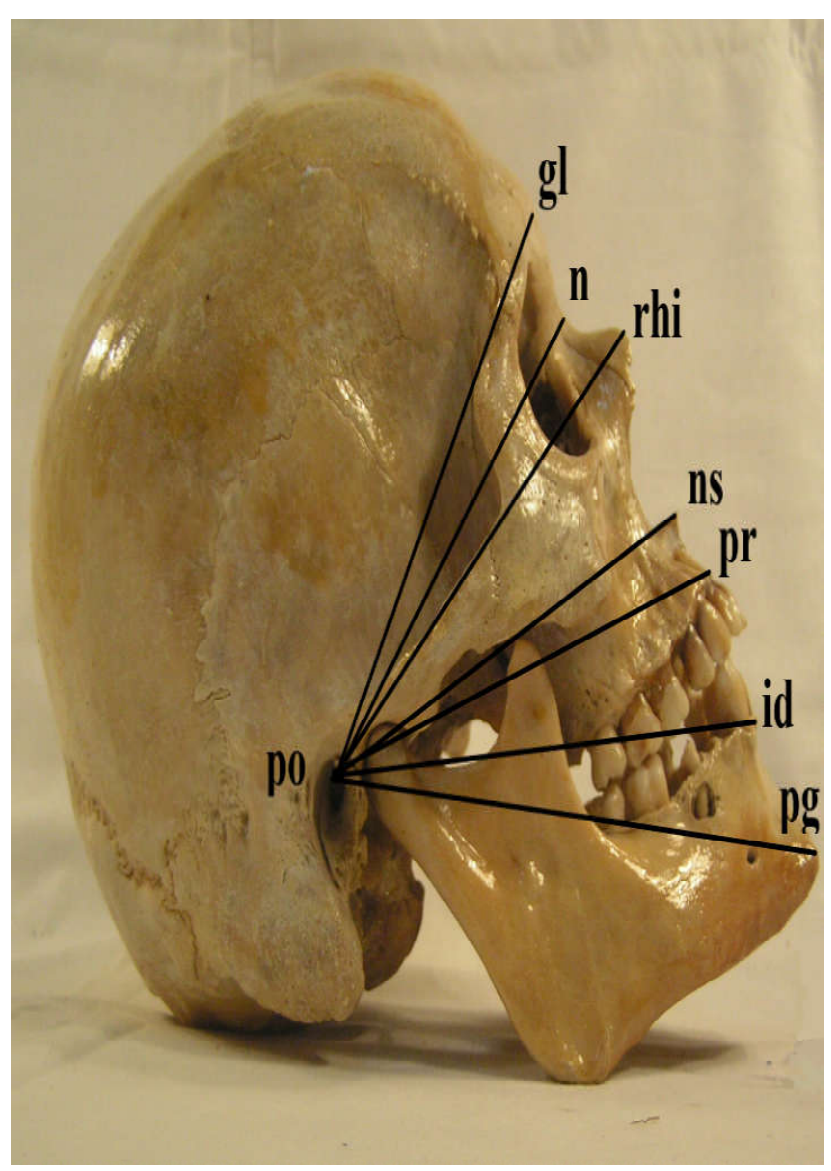

Fig.1. Visceral distances determination (sizes): A - in the frontal plane (frontal view); B - in the sagittal plane (lateral view). gl - glabella, zy - zygion, pg - pogonion, id - infradentale, pr - prosthion, ns - nasospinale, $\mathrm{n}$ - nasion, rhi - rhinion, po - porion. Photo of the skull's collection № 47. 
visceral index: Ind. visceral = n-gn / zy-zy x 100 .

For a more detailed analysis of individual anatomical variability of the visceral skull's shape and size, used an index to determine the height of upper part of the face using the formula: Ind..$_{2}$ (upper part of the face) = height of the upper part of the face (n-pr) / zygomatic size (zy-zy) x 100, where the height of the upper part of the face corresponds to the distance between the craniometric points nasion $(n)$ and prosthion (pr), and zygomatic width is - zygion-zygion (zy-zy). This index is depending on the main facial index with the subtraction of the mandible size.

In this study, the following six polygons of the visceral skull were studied: 1 - po-gl; 2 - po-n-rhi; 3 - po-rhi-ns; 4 po-ns-pr; 5 - po-pr-id; 6 - po-id-pg (Fig. 1).

Variation-statistical analysis of data measurements was carried out using the computer program "SPSS Statistics 17.0", which is one of the most well known and widely used nowadays. In our study, we used a common statistical analysis program that allowed us to determine the required parameters: the middle arithmetic $(\mathrm{X})$, the square deviation $(\sigma)$, and the middle error $(m)$. To confirm the reliability and to determine the correlation between the data obtained according individual anatomical variability, the FischerStudent criterion used, and the reliability criterion $(\rho)$ was determined according to special tables. All indicators were considered reliable at a value of $\rho \leq 0.05$.

\section{Results}

Obtained results of visceral skull craniometric measurements were analyzed and confirmed by statistical analysis (table 1).

It can be found from the table below that the highest range of the arithmetic average of zygomatic sizes (zy-zy) related with representatives of brachycephalic type of the skull: $\bar{x}=13.70 \mathrm{~cm}$ with $\sigma=2.80$ and $\mathrm{m}=0.91$ (males) and $\bar{x}=12.80 \mathrm{~cm}$ with $\sigma=1.99 \mathrm{i} \mathrm{m}=0.88$ (females). In adulthoods with mesocephalic type, it decreases to the level of statistical parameters: $\bar{x}=12.46 \mathrm{~cm}$ with $\sigma=2.86$ and $\mathrm{m}=0.86$ in males and $\bar{x}=12.10 \mathrm{~cm}$ with $\sigma=2.03$ and $\mathrm{m}=0.75$ in females. The minimal range has been found in dolichocephalic type of the head and skull, where $\bar{x}=$ $10.90 \mathrm{~cm}$ with $\sigma=3.30$ and $\mathrm{m}=0.98$ (males) and $\frac{x}{x}=$ $10.50 \mathrm{~cm}$ with $\sigma=2.87$ and $\mathrm{m}=0.86$ (females).

Consequently, reliable data of the sizes between the points of the external acoustic opening (po-po) is established, in brachycephalic males $-\bar{x}=12.88 \mathrm{~cm}$ (with $\sigma=2.32$ and $\mathrm{m}=0.82$ ) and females $-\bar{x}=12.32 \mathrm{~cm}$ (with $\sigma$ $=2.16$ and $\mathrm{m}=0.77)$. In mesocephalic $-\bar{x}=11.26 \mathrm{~cm}$ (with $\sigma=2.38$ and $\mathrm{m}=0.81$ ) and $\bar{x}=11.18 \mathrm{~cm}$ (with $\sigma=$ 2.41 and $\mathrm{m}=0.69)$; in dolichocephalic $-\bar{x}=10.20 \mathrm{~cm}$ (with $\sigma=2.57$ and $\mathrm{m}=0.87$ ) and $\bar{x}=9.801 \mathrm{~cm}$ (with $\sigma=$ 2.080 and $m=0.881$ ).

The lower zygomatic diameter - the size between points go-go, also decreases in the arithmetic average from brachycephalic to dolichocephalic types that is associated with the gradual narrowing and lengthening of the visceral skull in adulthood. So, in males with the brachycephalic type of the skull go-go reaches: $\bar{x}=11.21 \mathrm{~cm}$ with $\sigma=1.88$ and $m=0.43$, in females $-\bar{x}=10.93 \mathrm{~cm}$ with $\sigma=1.54$ and $\mathrm{m}=0.66$. With mesochephalic type respectively $\bar{x}=10.18$ $\mathrm{cm}$ with $\sigma=1.39$ and $\mathrm{m}=0.77$ and $\bar{x}=9.883 \mathrm{~cm}$ with $\sigma=$ 1.012 and $m=0.691$; dolichocephalic type of visceral parameter is $\bar{x}=9.463 \mathrm{~cm}$ with $\sigma=1.720$ and $\mathrm{m}=0.661$ (males) and $\bar{x}=9.010 \mathrm{~cm}$ with $\sigma=1.380$ and $\mathrm{m}=0.510$ (females).

More stable results were found determining the forehead width (ft-ft). This parameter tends to decrease from brachycephalic to dolichocephalic. More advanced type of facial structure is defined in brachycephalic adulthoods: $\bar{x}=8.600 \mathrm{~cm}$ with $\sigma=3.010$ and $\mathrm{m}=0.781$ and $\bar{x}=8.203$ $\mathrm{cm}$ with $\sigma=2.844$ and $\mathrm{m}=0.662$. The narrowed forehead shape related with dolichocephalic type: $\bar{x}=7.480 \mathrm{~cm}$ with $\sigma=2.234$ and $m=0.773$ (males) and $\bar{x}=7.184 \mathrm{~cm}$ with $\sigma=2.010$ and $m=0.891$ (females).

In addition, it is established the height range variability, which are directly dependent on the individual structure and shape of the visceral skull (table 1).

So, in males with the brachycephalic type of the skull determined the minimal range of the br-po arithmetic average $\bar{x}=13.95 \mathrm{~cm}$ with a significant sigmatic deviation $\sigma=4.38$ and $m=0.21$. Similarly, in females the range of brpo has the following statistical average: $\bar{x}=13.89 \mathrm{~cm}$ with $\sigma=4.01$ and $m=0.22$. In representatives with $a$ mesocephalic type of the skull, this parameter is in the average $\bar{x}=14.31 \mathrm{~cm}$ with $\sigma=3.21$ and $\mathrm{m}=0.25$ (males) and $\bar{x}=14.76 \mathrm{~cm}$ with $\sigma=3.99$ and $\mathrm{m}=0.198$ (females). In people with dolichocephalic skull type, the size br-po slightly increased: $\bar{x}=14.90 \mathrm{~cm}$ with $\sigma=2.81$ and $\mathrm{m}=$ 0.693 (males) and $\bar{x}=14.80 \mathrm{~cm}$ with $\sigma=2.36$ and $\mathrm{m}=$ 0.71 (females).

The next important parameter - is the height of the facial skull (n-gn), also reflects the existing range of variability depending on extreme forms of skull structure. In brachycephalic, the size of $\mathrm{n}$-gn is $\bar{x}=10.73 \mathrm{~cm}$ with $\sigma=$ 3.91 and $\mathrm{m}=0.12$ (males) and $\bar{x}=10.60 \mathrm{~cm}$ with $\sigma=3.02$ and $\mathrm{m}=0.22$ (females). In mesocephalic this facial parameter is in the range: males $-\bar{x}=10.91 \mathrm{~cm}$ with $\sigma=$ 1.93 and $\mathrm{m}=0.44$; in females $\bar{x}=10.89 \mathrm{~cm}$ with $\sigma=2.01$ and $\mathrm{m}=0.84$. In dolichocephalic, size reaches $\mathrm{n}-\mathrm{gn}: \bar{x}=$ $11.70 \mathrm{~cm}, \sigma=3.11, \mathrm{~m}=0.34$ (males) and $\bar{x}=11.60 \mathrm{~cm}, \sigma$ $=3.01, \mathrm{~m}=0.39$ (females).

For modern craniological estimation of the visceral skull, the size n-pr used to calculate special indices. According to our data, in brachycephalic males this parameter varies from 5.0 to $6.9 \mathrm{~cm}$ with $\bar{x}=5.732 \mathrm{~cm}, \sigma=2.941, \mathrm{~m}=0.534$; in females - between $4.8-6.6 \mathrm{~cm}$ with $\bar{x}=5.560 \mathrm{~cm}, \sigma=$ $2.452, \mathrm{~m}=0.451$. In representatives of mesocephalic type, the $\mathrm{n}-\mathrm{pr}$ ranges between $10.0-11.6 \mathrm{~cm}$ with $\bar{x}=6.110 \mathrm{~cm}$, $\sigma=2.483, \mathrm{~m}=0.532$ (males) and $\bar{x}=6.080 \mathrm{~cm}, \sigma=2.181$, $\mathrm{m}=0.440$ (females). In people with dolichocephalic type, this altitude parameter increased in males from 5.7 to 7.9 $\mathrm{cm}(\bar{x}=6.982 \mathrm{~cm}, \sigma=2.012, \mathrm{~m}=0.330)$, in females - 
Table 1. Statistical data of the visceral skull in adulthood $(\mathrm{cm})$.

\begin{tabular}{|c|c|c|c|c|c|c|c|c|c|c|}
\hline \multirow{3}{*}{\multicolumn{2}{|c|}{ Investigated signs }} & \multicolumn{9}{|c|}{ The shape of the skull } \\
\hline & & \multicolumn{3}{|c|}{ Brachycephalic } & \multicolumn{3}{|c|}{ Mesocephalic } & \multicolumn{3}{|c|}{ Dolichocephalic } \\
\hline & & $\bar{x}$ & $\sigma$ & $\mathrm{m}$ & $\bar{x}$ & $\sigma$ & $\mathrm{m}$ & $\bar{x}$ & $\sigma$ & $\mathrm{m}$ \\
\hline \multirow{2}{*}{$z y-z y$} & mal. & 13.70 & 2.80 & 0.91 & 12.46 & 2.66 & 0.86 & 10.90 & 3.30 & 0.98 \\
\hline & fem. & 12.80 & 1.99 & 0.88 & 12.10 & 2.03 & 0.75 & 10.50 & 2.87 & 0.86 \\
\hline \multirow{2}{*}{ po-po } & mal. & 12.88 & 2.32 & 0.82 & 11.26 & 2.38 & 0.81 & 10.20 & 2.57 & 0.97 \\
\hline & fem. & 12.32 & 2.16 & 0.77 & 11.18 & 2.41 & 0.79 & 9.801 & 2.080 & 0.881 \\
\hline \multirow{2}{*}{ go-go } & mal. & 11.21 & 1.88 & 0.43 & 10.18 & 1.33 & 0.77 & 9.463 & 1.720 & 0.661 \\
\hline & fem. & 10.83 & 1.54 & 0.66 & 9.883 & 1.012 & 0.691 & 9.010 & 1.380 & 0.510 \\
\hline \multirow{2}{*}{$\mathrm{ft}-\mathrm{ft}$} & mal. & 8.600 & 3.010 & 0.781 & 8.360 & 2.140 & 0.431 & 7.480 & 2.234 & 0.773 \\
\hline & fem. & 8.203 & 2.844 & 0.662 & 7.891 & 2.603 & 0.670 & 7.184 & 2.010 & 0.891 \\
\hline \multirow{2}{*}{ br-po } & mal. & 13.95 & 4.38 & 0.21 & 14.31 & 3.21 & 0.25 & 14.90 & 2.81 & 0.69 \\
\hline & fem. & 13.89 & 4.01 & 0.21 & 14.46 & 3.99 & 0.20 & 14.80 & 2.36 & 0.71 \\
\hline \multirow{2}{*}{ n-gn } & mal. & 10.73 & 3.91 & 0.12 & 10.91 & 1.93 & 0.44 & 11.70 & 3.11 & 0.24 \\
\hline & fem. & 10.60 & 3.02 & 0.22 & 10.89 & 2.01 & 0.81 & 11.60 & 3.01 & 0.91 \\
\hline \multirow{2}{*}{$\mathrm{n}-\mathrm{pr}$} & mal. & 5.732 & 2.941 & 0.534 & 6.110 & 2.483 & 0.532 & 6.982 & 2.012 & 0.330 \\
\hline & fem. & 5.560 & 2.452 & 0.451 & 6.080 & 2.181 & 0.440 & 6.761 & 1.993 & 0.394 \\
\hline \multirow{2}{*}{ n-po } & mal. & 10.39 & 1.12 & 1.41 & 10.58 & 1.05 & 0.98 & 11.47 & 1.31 & 0.65 \\
\hline & fem. & 10.47 & 1.10 & 1.48 & 10.65 & 1.28 & 0.87 & 11.30 & 1.11 & 0.81 \\
\hline \multirow{2}{*}{ pr-po } & mal. & 11.66 & 1.03 & 0.95 & 11.01 & 1.21 & 0.89 & 10.12 & 1.11 & 0.91 \\
\hline & fem. & 11.52 & 1.01 & 0.89 & 11.00 & 1.19 & 0.89 & 9.981 & 1.087 & 0.961 \\
\hline \multirow{2}{*}{ pg-po } & mal. & 12.66 & 2.01 & 0.99 & 12.86 & 1.12 & 0.99 & 13.90 & 1.07 & 0.85 \\
\hline & fem. & 12.48 & 1.86 & 0.99 & 12.70 & 1.20 & 0.69 & 13.82 & 1.28 & 0.76 \\
\hline
\end{tabular}

between $5.5-7.6 \mathrm{~cm}(\bar{x}=6.761 \mathrm{~cm}, \sigma=1.993, \mathrm{~m}=0.394)$.

To understand the limit of morphometric variability of the visceral skull of, some longitudinal parameters are of particular importance: n-po, pr-po and pg-po. They have the following range of variation in adulthood people (table 1).

The obtained data indicate that the distance between the points of intersection of the median plane with the frontonasal suture $(n)$ and the point of the external acoustic opening (po) is the smallest in males and females with brachycephalic type: $\bar{x}=10.39 \mathrm{~cm}, \sigma=1.12, \mathrm{~m}=1.41$ and $\bar{x}=10.47 \mathrm{~cm}, \sigma=1.10, \mathrm{~m}=1.48$. This parameter slightly increased in mesocephalic type: in males $\bar{x}=10.58 \mathrm{~cm}$ with $\sigma=1.05$ and $m=0.98$; in females $\bar{x}=10.65 \mathrm{~cm}, \sigma=$ $1.28, m=0.87$. The largest range of the size $n$-po are in the representatives of both genders dolichocephalic type: $\bar{x}=$ $11.47 \mathrm{~cm}(\sigma=1.31$ and $\mathrm{m}=0.65)$ and $\bar{x}=11.30 \mathrm{~cm}(\sigma=1.21$ and $m=0.81)$. These features emphasize the existing individual differences in the structure of the adulthood face, due to the significant range of variability of longitudinal parameters of the skull. In our opinion, this is due to the specific lengthening and narrowing of the upper part of the face in dolichocephalic people.

An important longitudinal size of the facial skull is the distance pr-po (table 1). From the mentioned table we can find that the size pr-po is the largest in males with brachycephalic structure of skull: $\bar{x}=11.66 \mathrm{~cm}$ with $\sigma=1.03$ and $\mathrm{m}=0.95$; in females $\bar{x}=11.52 \mathrm{~cm}, \sigma=1.10, \mathrm{~m}=1.48$. In mesocephalic structure of the skull a gradual decrease in the arithmetic average of this parameter is determined: $\bar{x}=$ $11.01 \mathrm{~cm}$ (with $\sigma=1.21$ and $\mathrm{m}=0.89$ ) and $\bar{x}=11.00 \mathrm{~cm}$ (with $\sigma=1.19$ and $m=0.89$ ). In dolichocephalic type, the greater decrease in the facial distance observed: for males $\bar{x}=10.12 \mathrm{~cm}(\sigma=1.11$ and $\mathrm{m}=0.91)$; in females $\bar{x}=9.981$ $\mathrm{cm}(\sigma=1.087$ and $\mathrm{m}=0.961)$.

The above-mentioned facts indicate a predominance of the pr-po distance in brachycephalic adulthood (round head); there is a specific convexity of the two halves of the maxilla along the midline with the pr point moving forward due to the particular curvature of the upper alveolar arch and position of the medial incisors. Therefore, in brachycephalic males the range of pr-po variability is determined - from 11.4 to $12.6 \mathrm{~cm}$, females - from 11.0 to $12.2 \mathrm{~cm}$. In mesocephalic of both genders, these longitudinal parameters gradually decrease and do not exceed - 9.4-11.7 and 9.0-11.2 cm (males and females). In the dolichocranic, the above parameters of the visceral skull is in the range between 8.90 to $11.6 \mathrm{~cm}$ and $8.8-11.4 \mathrm{~cm}$ (males and females).

The distance between points pg-po in craniomety become the most important, that is between protrusion of the mandible (or mental protuberance) to the external 
Table 2. The range of individual visceral indices variability in adulthood.

\begin{tabular}{|c|c|c|c|}
\hline \multicolumn{2}{|c|}{ The shape of the skull } & \multicolumn{2}{c|}{ Investigated signs } \\
\cline { 3 - 4 } \multicolumn{2}{|c|}{} & $\begin{array}{c}\text { Ind } \\
\text { 1 - visceral } \\
(\mathrm{n} \text {-gn) }\end{array}$ & $\begin{array}{c}\text { Ind }_{2} \text {-the upper part of } \\
\text { the visceral skull (n-pr) }\end{array}$ \\
\hline \multirow{2}{*}{ Brachycephalic } & males & $83.50 \pm 9.70$ & $49.25 \pm 4.45$ \\
\cline { 2 - 4 } & females & $87.00 \pm 7.80$ & $48.55 \pm 4.35$ \\
\hline \multirow{2}{*}{ Mesocephalic } & males & $86.00 \pm 3.20$ & $55.50 \pm 2.30$ \\
\cline { 2 - 4 } & females & $85.30 \pm 3.40$ & $54.80 \pm 4.40$ \\
\hline \multirow{2}{*}{ Dolichocephalic } & males & $91.20 \pm 4.40$ & $58.50 \pm 3.70$ \\
\cline { 2 - 4 } & females & $91.10 \pm 2.90$ & $58.20 \pm 2.60$ \\
\hline
\end{tabular}

acoustic opening. This parameter reflects the longitudinal size of the lower part of the visceral skull (table 1). It has been established that males with brachycephalic type of skull has an average of $\bar{x}=12.66 \mathrm{~cm}$ (with $\sigma=2.01, \mathrm{~m}=$ 0.99), in females $\bar{x}=12.48 \mathrm{~cm}$ (with $\sigma=1.86, \mathrm{~m}=0.99$ ). In males with mesocephalic type of visceral skull, there is a tendency to slight increase of $\bar{x}=12.86 \mathrm{~cm}$ (with $\sigma=1.12$ and $\mathrm{m}=0.99$ ); $\bar{x}=12.70 \mathrm{~cm}$ (with $\sigma=1.20$ and $\mathrm{m}=0.69$ ) in females. The maximal range of this size are typical for representatives of the dolichocephalic shape of head: $\bar{x}=$ $13.90 \mathrm{~cm}$ with $\sigma=1.02$ and $\mathrm{m}=0.85$ (males); $\bar{x}=13.82 \mathrm{~cm}$ with $\sigma=1.28$ and $m=0.76$ (females). The data mentioned above is associated with an increase in longitudinal parameters in dolichocephalic type, the narrowing and lengthening of the visceral skull is determined.

These latitudinal, longitudinal and high-altitude dimensions of the visceral skull allow us to establish the range of main indices variability depending on the three types of skull structure (table 2).

According to this table we can say that Ind (complete) has a wide range of variability, especially in brachycephalic males $-83.50 \pm 9.70$ and in females $-87.00 \pm 7.80$, which includes a variety of visceral skull structure in people of different age. The range of this index in mesocephalic people is less $-86.00 \pm 3.20$ (males) and $85.30 \pm 3.40$ (females). Accordingly, in dolichocephalic type complete visceral index is observed in range $-91.20 \pm 4.40$ (males) and $91.10 \pm$ 2.90 (females).

The additional visceral index $\left(\operatorname{lnd}_{2}\right)$ also repeats the existing features of the variability of individual structure and morphometric ratios (table 2).

It is clearly seen, that in brachycephalic adulthood this index varies in range $-49.25 \pm 4.45$ (males) and $48.55 \pm$ 4.35 (females); in mesocephalic it increases to $55.50 \pm 2.30$ (males) and $54.80 \pm 4.40$ (females); increases even more in dolichocephalic - $58.50 \pm 3.70$ (males) and $58.20 \pm 2.60$ (females).

\section{Discussion}

Analyzing the obtained data in adulthood the peculiar roundness of the oval of the visceral skull is determined, which is typical for the brachycephalic structure of the head; intermediate ovality - for mesocephalic type and narrowed oval face - for dolichocephalic type. The above results of our study greatly complement the information of outstanding morphologists and craniologists [2, 20, 21].

For the first time determined the range of variability of longitudinal parameters of the visceral skull, which is characteristic for males and females of adulthood. This all greatly complements our understanding about the structure and shape of the skull in people who live in our geographic area. Investigated parameters reflect the existing individual variability of the gradual extension and narrowing of the upper part of the facial skull, which is characteristic for representatives of dolichocephalic head type. On the contrary, this parameter of the facial skull more pronounced in brachycephalic adulthood due to the enlarged convexity of the two halves of the maxilla, the curvature of the upper alveolar arch and the forward displacement of the point (pr).

Calculated Ind $\mathrm{I}_{1}$ and $\mathrm{Ind}_{2}$ allowed establishing that in males and females between the ages of 25 and 60 , who have a brachycephalic type of the skull, the most commonly defined euriprosopic type of the skull with a characteristic increase in all transverse parameters and, more rarely, the mesoprosopic type with moderate values of parameters. Otherwise, broad-head people have an enlarged or average shape of the skull, which depends on the established morphometric indices and the range of their differences.

In adulthoods with mesocephalic type of the skull, the mesoprosopic type of the facial skull with moderate values are often detected.

In dolichocephalic people of this age, the most common is leptoprosopic type of the visceral skull with a characteristic predominance of longitudinal parameters. Less commonly, there is a mesoprosopic type with a set of averaged indicators. The narrow-head people determined with combination of a narrow or middle shape of the visceral skull, which is fully confirmed by the obtained variationstatistical data. The obtained data are important for further studying the shape, size, position, relationship with the visceral part of the skull and the craniometric features of the upper and lower jaws. Without this, it is impossible to establish the existing range of individual anatomical variability of the visceral skull and its structures [19, 26].

So, a further investigation of individual anatomical variability is considered to be important, the shape, size, localization, features of visceral skull in adulthood males and females. Depending on the range of variability of individual parameters of the visceral skull - it will be possible to suggest the most effective and rational ways of surgical interventions and accesses.

\section{Conclusions}

1. It was proved that the obtained morphometric consistent patterns reflect the existing ratio of transvers parameters, determined by the type of visceral skull. In brachycephalic type, all indicators of visceral width are greater due to an increase in the head size and round 
shape head. In mesocephalic type, there are a gradual decrease in facial indicators in average of $0.6-0.8 \mathrm{~cm}$, which is associated with the tendency of midhead formation. In case of dolichocephalic type, the width decreases over all specified visceral distances and appeared the formation of narrow head.

2. Thus, it is also proved that the specific type of visceral skull - europrosopic is specific for the people of Kharkiv region. It is characterized by increased latitudinal sizes: $z y-$ zy, po-po and go-go, with a slight decrease in altitude parameters of the visceral skull $n-g n$ and $n-p r$. This

\section{References}

[1] Ashok, S., Gupta, A., Ashok, K., \& Mhaske, S. A. (2016) Peripheral ossifying fibroma: A rare case affecting maxillary region. Indian Journal Dentistry, 7(3), 141-143. doi: 10.4103/ 0975-962X.186701

[2] Del Neri, N. B., Araujo-Pires, A. C., Andreo, J. C., Rubira-Bullen, I. R., \& Ferreira O. J. (2014). Zygomaticofacial foramen location accuracy and reliability in cone-beam computed tomography. Acta Odontologica Scandinavica, 72(2), 157-160. doi: 10.3109/ 00016357.2013.814804

[3] Ewers, R., Marincola, M., \& Morgan, V. (2018). Restoration of the atrophic maxilla with four narrow and ultrashort implants. International Journal of Clinical Oral and Maxillofacial Surgery, 4(2), 35-41. doi: 10.11648/j.jicoms.20180402.11

[4] El Bouihi, M., Bouaichi, A., Lahmiti, S., Abouelhassan, T., Samkaoui, A., \& Mansouri-Hattab, N. (2013). Submental intubation in maxillofacial traumatology. Revue de stomatologie, de chirurgie maxillo-faciale et de chirurgie orale, 114(3), 155-158. doi: 10.1016/j.revsto.2013.03.006

[5] Farlie, P. G. (2016). Frontonasal Dysplasia: Towards an Understanding of Molecular and Developmental Aetiology. Molecular Syndromology, 7(6), 312-321. doi: 10.1159/ 000450533

[6] Fearon, J. A. (2014). Evidence-based medicine: craniosynostosis. Plastic and Reconstructive Surgery, 133 (5), 1261-1275. doi: 10.1097/PRS.0000000000000093

[7] Fukuda, M., Matsunaga, S., Odaka, K., Oomine, Y., Kasahara, M., Yamamoto, M., \&Abe, S. (2015). Three-dimensional analysis of incisive canals in human dentulous and edentulous maxillary bones. International Journal of Implant Dentistry, 1(1), 12. doi: 10.1186/s40729-015-0012-4

[8] Hanawa, S., Kitaoka, A., Koyama, S., \& Sasaki, K. (2015). Influence of maxillary obturator prostheses on facial morphology in patients with unilateral maxillary defects. The Journal of Prosthetic Dentistry, 113(1), 62-70. doi: 10.1016/ j.prosdent.2014.06.016.

[9] Hoffman, D. (2015). Complications of TMJ surgery. Oral Maxillofacial Surgery and Clinical Northern America, 27 (1), 109-124. doi: 10.1016/j.coms.2014.09.008

[10] Huiskes, F. (2013). Bitemporal hemianopsia in frontonasal dysplasia, callosal agenesis, basal meningocele and eye abnormalities. Journal of Neurology, Neurosurgery \& Psychiatry, 84, 915-917. doi: 10.1136/jnnp-2012-304741

[11] Kim, D. H., Choi, Y. H., Yun, S. J., \& Lee, S. H. (2018). Diagnostic performance of brain computed tomography to detect facial bone fractures. Clinical and Experimental Emergency Medicine, 5(2), 107-112. doi: 10.15441/ceem.17.223

[12] Kun-Darbois, J.D., Guillaume, B., \& Chappard, D. (2017). Asymmetric bone remodeling in mandibular and maxillary tori. evidenced by the range of the complete and additional visceral indices ( $\operatorname{lnd}_{1}$ and $\operatorname{lnd}_{2}$ ). Representatives of mesoprosopic type also belong to this type of visceral skull structure, characterized by increased latitudinal dimensions depending on the shape of the head (round head). The similar features of visceral skull morphological structure are determined in females of this age. Less often, there are leptoprosopic types of face in young people, characterized by an increase in altitude and longitudinal parameters (n-gn and n-pr) with a marked decrease in zygomatic sizes (zy-zy).

Clinical Oral Investigations, 21(9), 2781-2788. doi: 10.1007/ s00784-017-2080-8

[13] Lockwood, P. (2017). CT sinus and facial bones reporting by radiographers: findings of an accredited postgraduate programme. Dentomaxillofacial Radiology, 46(5), 20160440. doi: 10.1259/dmfr.20160440

[14] Monje, A., Urban, I. A., \& Miron, R. J. (2017). Morphologic Patterns of the Atrophic Posterior Maxilla and Clinical Implications for Bone Regenerative Therapy. International Journal of Periodontics Restorative Dentistry, 37(5), 279289. doi: $10.11607 /$ prd.3228

[15] Przystanska, A., Kulczyk, T., Rewekant, A., Sroka, A., Jonzyk-Potoczna, K., Gawriolek, K., \& Czajka-Jakubowska, A. (2018). The Association between Maxillary Sinus Dimensions and Midface Parameters during Human Postnatal Growth. Biomed Research International, 15; 10. doi: $10.1155 / 2018 / 6391465$

[16] Ranganathan, K. (2015). Comparative effectiveness studies examining patient reported outcomes among children with cleft lip and/or palate: a systematic review. Plastic and reconstructive surgery, 135 (1), 198-211. doi: 10.1097/ PRS. 000000000000025

[17] Shen, L., Ai, H., Liang, Y., Ren, X., Anthony, C.B., Goodlett, C.R., Zhou, F.C. (2013). Effect of prenatal alcohol exposure on bony craniofacial development: a mouse MicroCT study. Alcohol, 47(5), 405-415. doi: 10.1016/j.alcohol.2013.04.005

[18] Smirnov, V. G., Janushevich, O. O., Mitronin, V. A. (2014). Clinical Anatomy of the Jaws. Moscow: Binom.

[19] Tak, H. J., Park, T. J., Piao, Z., \& Lee, S. H. (2017). Separate development of the maxilla and mandible is controlled by regional signaling of the maxillomandibular junction during avian development. Developmental Dynamics, 246(1), 28-40. doi: $10.1002 / d v d y .24465$

[20] Thiesen, G., Gribel, B. F., Kim, K. B., \& Freitas, M. P. M. (2017). Maxillofacial Features Related to Mandibular Asymmetries in Skeletal Class III Patients. Journal of Oral and Maxillofacial Surgery, 75(5), 1015-1025. doi: 10.1016/j.joms.2016.11.011

[21] Thiesen, G., Freitas, M. P. M., Araujo, E. A., Gribel, B. F., \& Kim, K. B. (2018). Three-dimensional evaluation of craniofacial characteristics related to mandibular asymmetries in skeletal Class I patients. American Journal of Orthodontics and Dentofacial Orthopedics, 154(1), 91-98. doi: 10.1016/ j.ajodo.2017.10.031

[22] Vovk, Yu. N., \& Vovk, O. Yu. (2016). Perspectives and new directions of the doctrine of individual anatomical variability. Bulletin of problems in biology and medicine, 1(2), 376-379. doi: org/10.24061/103944

[23] Vovk, Yu. N., Vovk, O. Yu., \& Ikramov, V. B. (2016). Practical 
significance of individual anatomical variability for modern craniology. Clinical anatomy and operative surgery, 15 (1), 105-109. doi: org/10.31174/SEND-NT2018-186VI22-01

[24] Wang, Y. T., Huang, S. F., Fang, Y. T., Huang, S. C., Cheng, H. F., Chen, C. H., ... Lin, C.L. (2018). Anatomical Thin Titanium Mesh Plate Structural Optimization for Zygomatic-Maxillary Complex Fracture under Fatigue Testing. Biomed Research International, 20, 93-98. doi: 10.1155/2018/9398647

[25] Winston, K.R., Beauchamp, K., \& Harasaki, Y. (2017). Everting
Fracture of Entire Frontal Bone: Management and Importance of Preliminary Reconstruction. Journal of Craniofacial Surgery, 28(4), 1090-1092. doi: 10.1097/SCS.0000000000003560

[26] Zhang, Y., Lin, Y., Liu, Y., Luo, J., Di, P., \& Ma, T. (2017). Lateral cephalometric analysis of patients with maxillary alveolar protrusion and advanced periodontitis treated with immediate implants and cross-arch fixed prostheses. Chinese Journal of Stomatology, 52(10), 625-630. doi: 10.3760/cma.j.issn.10020098.2017.10.009

\section{КРАНІОМЕТРИЧНА ХАРАКТЕРИСТИКА ЛИЦЬОВОГО ВІДДІЛУ ЧЕРЕПА ЛЮДИНИ ЗРІЛОГО ВІКУ}

\section{Сазонова О. М., Вовк О. Ю., Вовк Ю. М., Гордійчук Д. О., Дубина С. О.}

У зв'язку з розвитком клінічної ендовазивної хірургії, нейрохірургії, щелепно-лицьової хірургії, виникає гостра необхідність в їх удосконаленні. В останні роки швидко розвиваються остеологічні та ортопедичні напрямки медицини, що потребують додаткових даних з вікової та індивідуальної анатомічної мінливості. Мета дослідження - встановлення діапазону анатомічної мінливості лицьового черепа у людей зрілого віку з визначенням крайніх фрорм, розмірів та взаємовідношень у відповідності з формами черепа людини. Дослідження проведено за допомогою вивчення 100 кісткових препаратів цілісних та фррагментованих черепів, що увійшли до колекції кафредри анатомії людини Харківського національного медичного університету. У дослідженні застосовувалися 58 черепів чоловіків та 42 черепа жінок віком 25-60 років. Для встановлення індивідуальної анатомічної мінливості кісткових структур в дослідженні визначався ряд основних індексів за допомогою краніоциркуля. Всі розрахунки проводилися згідно комп'ютерної програми "SPSS Statistics 17.0" з використанням цифррових таблиць і стандартного пакету вихідних даних. Встановлено, що найбільші значення середньої арифметичної виличного розміру (zу-zу) характерні для представників з брахіморфрною фрормою черепа, у осіб з мезоморфрною фрормою визначено зменшення величини даного показника, мінімальні значення характерні для доліхоцефралічної форми голови та черепа. Для нижньовиличного діаметра - розмірів між точками gо-gо, також, характерне зменшення значень середньої арифрметичної від брахі- до доліхокранів, що пов'язано з поступовим звуженням і подовженням лицьового черепа останніх. Більш стабільні значення виявлені при визначенні ширини чола (ft-ft). Даний параметр має тенденцію до зменшення від брахікранів до доліхокранів. Більш розширений тип будови чола визначається у брахіморфних людей, звужена форма чола характерна для доліхоморфнни людей. Для сучасної краніологічної оцінки лицьового черепа велике значення має і розмір п-рr, застосовуваний для обчислення спеціальних індексів. Зәідно з нашими даними, у чоловіків брахіморфного типу статури даний параметр змінюється від 5,0 до 6,9 см; у жінок - від 4,8 до 6,6 см. У представників мезоморфної статури розмір п-рг коливається від 10,0 до 11,6 см. У людей з доліхоморфною статурою даний висотний параметр у чоловіків від 5,7 до 7,9 см, у жінок - від 5,5 до 7,6 см. Також з'ясовано, що Ind1 (лицьовий) має широкий діапазон варіабельності, особливо у брахікранів чоловічої статі $(83,50 \pm 9,70)$ і жіночої статі $(87,00 \pm 7,80)$, що включає різноманітність типів будови лицьового відділу черепа у людей різного

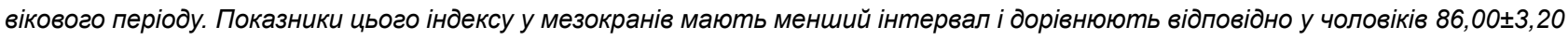

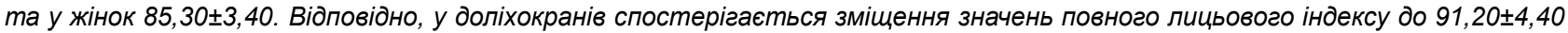

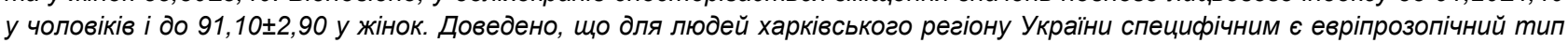
лицьового черепа, який характеризується збільшеними поперечними розмірами: zy-zy, ро-ро i go-go при незначному зменшенні висотних параметрів лицьового черепа $n$-gn та n-pr. Залежно від діапазону мінливості окремих параметрів лицьового черепа буде можливим запропонувати найбільш ефективні і раціональні способи корекції оперативних втручань та доступів. Ключові слова: краніометрія, індивідуальна анатомічна мінливість, лицьовий череп, зрілий вік.

\section{КРАНИОМЕТРИЧЕСКИЕ ХАРАКТЕРИСТИКА ЛИЦЕВОГО ОТДЕЛА ЧЕРЕПА ЧЕЛОВЕКА ЗРЕЛОГО ВОЗРАСТА}

\section{Сазонова О. Н., Вовк О. Ю., Вовк Ю. М., Гордийчук Д. А., Дубина С. А.}

В связи с развитием клинической эндовазивной хирургии, нейрохирургии, челюстно-лицевой хирургии, возникает острая необходимость в их совершенствовании. В последние годы быстро развиваются остеологические и ортопедические направления медицины, требуют дополнительных данных по возрастной и индивидуальной анатомической изменчивости. Цель исследования - установление диапазона анатомической изменчивости лицевого черепа у людей зрелого возраста с определением крайних форм, размеров и взаимоотношений в соответствии с фоормами черепа человека. Исследование проведено с помощью изучения 100 костных препаратов челостных и фррагментированных черепов, вошедших в коллекцию кафредры анатомии человека Харьковского национального медицинского университета. В исследовании использовались 58 черепов мужчин и 42 черепа женщин в возрасте 25-60 лет. Для установления индивидуальной анатомической изменчивости костных структур в исследовании определялся ряд основных индексов с помощью краниоциркуля. Все расчеты проводились согласно компьютерной программы "SPSS Statistics 17.0" с использованием иифровых таблиц и стандартного пакета исходных данных. Установлено, что наибольшие значения средней арифретической скулового размера (zу-zу) характерны для представителей брахиморфной формы черепа, у лии с мезоморфной формой - определено уменьшение величины данного показателя, минимальные значения характерны для долихоцефалической формы головы и черепа. Для нижнескулового диаметра - размера между точками gо-gо, также характерно уменьшение значений средней арифрметической от брахи- к долихокранам, что связано с постепенным сужением и удлинением лицевого черепа последних. Более стабильные значения обнаружены при определении ширины лба (ft-ft). Данный параметр имеет тенденцию к уменьщению от брахикранов к долихокранам. Более расширенный тип строения лица определяется у брахиморфных людей, суженная форма лица характерна для долихоморфных людей. Для современной краниологической оценки лицевого черепа большое значение имеет и размер n-pr, применяемый для вычисления специальных индексов. Согласно нашим данным, у мужчин брахиморфрного 
типа телосложения данный параметр изменяется от 5,0 до 6,9 см; у женщин - от 4,8 до 6,6 см. У представителей с мезоморфным телосложения размер n-pr колеблется от 10,0 до 11,6 см. У людей с долихоморфным телосложением данный высотный параметр у мужчин от 5,7 до 7,9 cм, у женщин - от 5,5 до 7,6 см. Также установлено, что Ind1 (лицевой) имеет широкий диапазон вариабельности, особенно у брахикранов мужского пола $(83,50 \pm 9,70)$ и женского пола $(87,00 \pm 7,80)$, включающий разнообразие типов строения лицевого отдела черепа у людей разного возрастного периода. Показатели этого индекса у мезокранов имеют меньший интервал и равны соответственно у мужчин 86,00 $\pm 3,20$ и у женщин 85,30 \pm 3,40. Соответственно, у долихокранов наблюдается смещение значений полного лицевого индекса до 91,20 4 4,40 у мужчин и до 91,10 \pm 2,90 у женщин. Доказано, что для людей харьковского региона Украины специфическим является европрозопический тип лицевого черепа, который характеризуется увеличенными поперечных размеров: zy-zу, ро-ро и go-go при незначительном уменьшении высотных параметров лицевого черепа n-gn и n-pr. B зависимости от диапазона изменчивости отдельных параметров лицевого черепа будет возможным предложить наиболее эфррективные и рациональные способы коррекции оперативных вмешательств и доступов.

Ключевые слова: краниометрия, индивидуальная анатомическая изменчивость, лицевой череп, зрелый возраст. 